\title{
Reforms in the Oil and Gas Sector in Nigeria from 1999 - 2021: A Critical Appraisal
}

\author{
Mmecha Helen Oziri ${ }^{*}$, Mmecha Christopher Achinike ${ }^{2}$ \\ ${ }^{\mathrm{T}}$ Department of Sociology Faculty of Social Sciences University of Port Harcourt Choba, Nigeria \\ ${ }^{2}$ Nigerian Agip Oil Company Rivers State, Nigeria
}

\section{*Corresponding Author}

Mmecha, Helen Oziri

\section{Article History}

Received: 06.11.2021

Accepted: 13.12 .2021

Published: 19.01.2022

\begin{abstract}
The Nigerian oil and gas sector has suffered a lot of setbacks since the commencement of the production of oil in large quantities. This situation becomes more worrisome for the fact that the oil and gas sector produces petroleum resources which represent the economic mainstay of the country and until recently, was a major employer of labour. This paper examined some factors responsible for the state of decay and dwindling fortunes in the sector and noted that these issues have been pervasive for a long time. The oil and gas sector has been beset by the challenge of non-implementation of or the implementation of ineffective reforms and regulations, the high level of oil theft and pipeline vandalism, systemic corruption and unethical practices by both the local and international players, lack of effective legal and institutional frameworks which should enhance regulatory functions, ineffective leadership, etc. The information used for this paper were gathered from secondary sources. A critical appraisal of the activities of the sector showed that a lot needs to be done by the present Government, especially with the passing of the Petroleum Industry Bill (PIB). The paper adopted the concept of Pockets of Effectiveness to posit that even in the midst of such decay, Government agencies and public organizations can achieve effectiveness but must eschew the mentality of rent-seeking, patronage and clientelism which characterize the oil and gas sector in Nigeria.
\end{abstract}

Keywords: Oil and Gas sector, reforms.

\section{INTRODUCTION}

Every country has major economic bedrock that is expected to sustain the economy. Different countries are known for their different economic mainstay. Nigeria was economically dependent on agricultural produce and export even before 1960 (Ogen, 2003). However, this dependence on agriculture shifted to petroleum resources (Saidu \& Abdel, 2014) when oil was discovered in Oloibiri in present day Bayelsa State in 1956 (Ameh, 2006, Ogbuigwe, 2018). Oil therefore became the economic mainstay of Nigeria (Donwa, Mgbame, \& Ogbeide, 2015; Olujobi, 2021; Ikwueto \& Akpan, 2021). As a result, the agriculture sector was neglected (Chukwunka, 2013; Obioma, 2021).

Nigerian economy experienced a boom in the 1970s as a result of the excess money accrued from the export of petroleum products. However, the leadership style, ideology, and agenda introduced and implemented by different military leaders throughout the many years of successive military regimes ushered in a different experience for Nigerians; an experience that compromised the present generation and is still jeopardizing the development of future generations. Looting of the commonwealth was commonplace and corrupt practices became a systemic phenomenon (Aghalino, 2006; Olujobi, 2021).

Records show that as at 2012, Nigeria had ventured into deep water drilling, had natural gas reserves of 187 trillion cubic feet, barrels of oil reserves standing at 37.2 billion (Laba, 2012) and had become the largest oil-producing country in Africa. Ninety percent of foreign exchange incomes are realized from the oil and gas sector which constitutes $60 \%$ of the total revenue KPMG, 2021). It is rather unfortunate that the contribution of the oil and gas sector to the country's GDP has dropped from 13\% to about 7\% in 2020 (PwC, 2020).

Copyright @ 2021 The Author(s): This is an open-access article distributed under the terms of the Creative Commons Attribution 4.0 International License (CC BY-NC 4.0) which permits unrestricted use, distribution, and reproduction in any medium for noncommercial use provided the original author and source are credited. 
The Nigerian National Oil Corporation was the first state-owned petroleum out-fit and was renamed Nigerian National Petroleum Corporation (NNPC) in 1977 with four refineries located at different parts of the country: two in Port Harcourt, one in Warri and one in Kaduna (Akpata, 2014; Wapner, 2017). The NNPC was created to oversee the various processes and stages involved in the upstream and downstream oil industry for the purpose of boosting their performance (Olujobi, 2021).

Iledare (2008) considered the numerous opportunities created by the large quantity of petroleum resources in Nigeria, and opined that there are endless choices to make which are expected to serve as guidelines for all the activities in the sector. The question is that comes to mind is 'Has Nigeria made result-oriented decisions over the years? The choices Nigeria has made over the years since the discovery of oil appear not to have achieved desired results. This observation may not be far from the truth considering the level of systemic decay in the sector (Joab-Peterside, 2015).

The inability to achieve desired results could be attributed to factors such as ineffective leadership style, weak legislations and reforms, poor implementation of reforms and regulatory laws, inappropriate institutional and structural framework, interference by International Oil Companies (IOCs), corruption, etc. (Ikwueto \& Akpan, 2021). Olujobi, (2021) also opined that the problems besetting the oil and gas industry include a high level of corruption, embezzlement of the proceeds from the sale of petroleum products and wanton pipeline vandalism. Eight hundred and eight billion naira was lost to pipeline vandalism and theft in nine years (Olujobi, 2021).

Militancy in the Niger Delta region was a menacing phenomenon. The oil and gas sector suffered greatly as a result of the problems inherent in the social relations between the people of the region and the IOCs and by extension the Federal Government. Amnesty International reported that militancy-related activities brought about a high death toll (Joab-Peterside, 2015). The Federal Government Post Amnesty Programme (PAP) initiated in 2009 was to last for five years and it brought about relative stability in the region, however the renewed hostility in the Niger Delta region was triggered by various reasons including the inability of the trained ex-militants to gain employment (Ebiede, 2017).

The Federal Government, in order to solve some of the problems in the oil and gas sector and create infrastructure, economic and social frameworks which would ensure that the sector is repositioned for better achievements, has over the years come up with different reforms in the industry. The objectives of the reforms in the oil and gas sector are: The restructuring of the Nigerian National Petroleum Corporation and its subsidiaries in order to enhance the sustainability of the abundant resources from the oil and gas sector; to enhance its impact on all stakeholders, including the host communities; to promote an efficient and effective service delivery and be able to meet the social and economic needs of the people (Laba, 2012).

The question is: have the reforms in the oil and gas sector been able to achieve desired results over these long years of implementation?

\section{Theoretical Framework}

This paper adopted the concept of Pockets of Effectiveness (PoEs) as a framework. Pockets of Effectiveness according to Roll (2014) are regarded as organizations which are effective to a large extent in performing their roles/functions and in meeting the needs of the environment or public irrespective of the fact that they carry out their activities in environments replete with large-scale ineffective agencies which are also enmeshed in corruption. In other words, PoEs are public organizations which are relatively effective in providing public goods and services in line with their mandates despite having to operate in an environment where effective public service is not common.

The general notion is that developing countries have weak systems of governance, especially among public sector agencies and organizations which are perceived as corrupt and dysfunctional; a situation brought about by bad governance. Roll (2014) opined that even in such environments, there is evidence of pockets of effectiveness among some organizations and it is common to find such agencies among weak institutions. Roll posited that PoEs is linked to a strong sense of organizational goals and interest in public service and these factors account for the development and sustenance of the PoEs. He however identified some features of such agencies:

(a) The presence of a strong executive that has the ability to protect an agency from rent-seeking and equally influential groups in the same environment.

(b) The operations of authorized autonomy to provide the required enablement for such agencies to operate without the encumbrances of numerous regulations, especially in the areas of finance, labour force and guidelines.

(c) An organizational culture that gives priority to the recruitment of only qualified candidates without recourse to appointment on the basis of political patronage or other sentiments. 
In the context of developing countries, some government organizations are observed to have performed relatively well in the midst of unfavourable and challenging environment. Pockets of Effectiveness are therefore adopted to assess public sector performance (Roll, 2014).

This Paper highlighted some major reforms/legislations in the oil and gas sector from $1999-2021$, in a bid to critically assess the performance of the Oil and gas sector.

\section{Oil and gas sector reform implementation committee (ogic) 2000}

In April 24, 2000, former President Olusegun Obasanjo who assumed office in 1999 inaugurated the OGIC which was regarded as the first Committee to be set up for the purpose of developing a pragmatic frame work that would focus on the Petroleum revenue inflows and the creation of synergy between the petroleum and non-petroleum sectors of the economy (Iledare, 2008). However, the need for a reconstituted OGIC arose because of the inability of the Obasanjoled Government to ensure a complete implementation of the recommendations of the OGIC which were expected to restructure the sector.

\section{National oil and gas policy (nogp) 2007}

In 2007, late President Umaru Musa Yar'adua appointed Dr. Rilwanu Lukman as Chairman of the reconstituted OGIC which was mandated to adapt the existing OGIC recommendations in producing workable institutional structures for the management of the oil and gas sector with the aim of repositioning the country's GDP in the world economy (Iledare, 2008). The National Oil and Gas Policy (NOGP) emerged from the OGIC mandate (Iledare, 2008). The National Oil and Gas Policy (NOGP) became important because of the need to delineate the structural boundaries between those who do business in the oil and gas sector and those agencies which have the responsibility to make oil and gas policies, regulations, and also monitor the sector (Iledare, 2008), and to transform the sector to meet global trends (Egbogah, 2013); (Nwapi, 2017).

\section{Gas master plan 2008}

The underdevelopment of the Nigerian oil and gas sector is said to be hinged on the dearth of gas infrastructure and the massive gas flaring taking place in the Niger Delta region. In response to this problem, the Gas Master Plan was put together by the Federal Government in 2008 and is being presently implemented. Olaniwun (2013) stated that the main objective of the Gas Master Plan is to promote gas production (Nigeria has a staggering amount of gas reserves which represents $2.82 \%$ of the world's reserves) and the supply of natural gas to the power industry (Ahimie, 2020).

\section{The local content act 2010}

It was observed that in all these years of petroleum resources exploitation, production, and distribution, there was a noticeable absence of Nigerians in these activities; about $90 \%$ of the machinery are imported and the employees occupying key positions were foreigners. The aim of the Local Content Law was to increase indigenous involvement in the oil and gas sector by institutionalizing a minimum benchmark for the use of local services and the promotion of indigenous employment (Temitope, 2015; Resolution Law Firm, 2020).

\section{Joint Ventures (Jvs)}

Activities in the oil and gas sector are governed by various agreements and arrangements. One of them is the Joint Ventures (JVs) and Production Sharing Contracts (PSCs) which are formal arrangements between Nigeria represented by NNPC and a counterpart International Oil Company (IOC) where both parties hold equity jointly (PwC, 2021). Both parties are therefore responsible for the funding of the exploration, development and production of petroleum and other related products.

\section{Key legislation and regulatory structures}

The following new regulatory laws were introduced: Petroleum Act Cap 10 LFN 2004 also known as the Petroleum Act, NNPC Act Cap N123 LFN 2004 also known as the NNPC Act, Associated Gas Reinjection Act 2004, Associated Gas Reinjection Amendment Act 2004, Petroleum Profit Tax Cap P12 LFN (PPTA) 2004, and the Nigerian Oil and Gas Industry Content Development Act 2010 (NCDA) (Jubril \& Abdullahi, 2020).

However, the Federal Ministry of Petroleum Resources is mandated to perform regulatory oversight function in the oil and gas sector and the Ministry does this through the Department of Petroleum Resources (DPR) and other agencies such as Petroleum Products Pricing Regulatory Agency (PPPRA) which regulates the pricing mechanism for the transportation and distribution of petroleum products, Federal Ministry of Environment which approves Environmental Impact Assessment (EIA) reports, Nigerian Content Development and Monitoring Board which ensures compliance with NCA, and the Joint Development Authority which supervises the Petroleum operations of the Nigerian-Soa Tome Principe Joint Development Authority (Olaniwun, 2013). The Nigerian National Petroleum Corporation (NNPC) as the 
state-owned organization that represents the interest of Nigeria in the oil and gas industry has the responsibility to implement Federal Government's policies on petroleum resources (Olaniwun, 2013; Jubril \& Abdullahi, 2020).

\section{President muhammadu buhari's reforms in the oil and gas sector}

The Federal Government under the leadership of Muhammadu Buhari commenced its reforms in the oil and gas sector by dismissing the NNPC Board and appointing Dr. Ibe Kachukwu as the Group Managing Director of NNPC. Nigerians were informed that NNPC would be restructured, and that the menace of illegal oil theft and the problem of fiscal terms which control the oil and gas sector would be addressed. After a long wait for the ministerial appointments, President Buhari finally announced that he would be the Minister of Petroleum Resources (Niger Reporters, Saturday, Nov 12, 2016), a pronouncement which shocked Nigerians. Dr. Maikanti Kachalla Baru replaced Dr. Ibe Kachikwu as NNPC's Group Managing Director. However, Mallam Mele Kyari is now the Group Managing Director of NNPC while the Minister of State for Petroleum for Nigeria is H.E. Chief Timipre Sylva. They were appointed in 2019 (African Energy Chambers, 2021).

President Buhari's change agenda in the oil and gas sector is therefore expected to produce reforms which are targeted at curbing the high level of mismanagement, corrupt practices and the issue of oil theft. Maduekwe (2016) opined that these conditions can only promote stability, profit maximisation, probity and accountability in the oil and gas sector.

It is note-worthy to mention that the issue of crude oil theft is a pathological problem in Nigeria and remains a major conduit pipe through which the government and oil companies lose revenues. This caused a drop of crude oil production from an estimated 2.3 million barrels to about 1.56 million bpd in 2015 (Kelly, 2015). It is reported that since 2008, more than US $\$ 100$ billion were lost through oil theft and leakages from the numerous vandalised pipelines. As expected, the clamp down on oil thieves through increased military surveillance, destruction of illegal refineries and the arrest of suspects drastically reduced such activities but it created a resurgence of violent militancy (Kelly, 2015). Unfortunately, the theft of oil resources and the activities of illicit refineries were curtailed to a reasonable extent in Bayelsa State but have presently taken an alarming dimension in Rivers State (Elem, 2021) and without Government intervention.

The Federal Government announced the removal of the fuel subsidy in 2016 and the pump price of fuel was pegged at N145 per litre. This produced mixed reactions from Nigerians (even though the issue of oil subsidy removal is still pending till today (TheGuardian Newspaper, April, 2021). The then Minister of Petroleum Resources stated that the new approved pump price would prevent the drain in the oil and gas sector as well as save a monthly N165 billion (Guardian, Sat. May, 2016). Nigerians had demanded that the refineries should be re-commissioned and fuel produced in the country to reduce the price and to ensure regular supply of the product. However the Federal Government argued that it was more expensive to produce refined crude oil in Nigeria than outside Nigeria; that the cost of producing refined crude was $\$ 118.5$ in Nigeria whereas it costs only $\$ 5.2$ outside Nigeria.

Deregulation of the downstream oil sector provides equal opportunity for interested persons/players to import petroleum products while Government regulators monitor their activities to ensure strict compliance with extant policies and guidelines. However, deregulation of the oil and gas sector which was announced before March, 2020, only created selfish businessmen and women who have been conferred monopolistic control over the market and whose activities deliberately destroyed the operations of demand and supply. Consequently, pump prices are in a constant but irregular change default to the detriment of the helpless consumers (Ahimie, 2020).

Nigeria's dependence on the importation of large quantities of refined petroleum products to meet the needs of the large populace belies the fact that she is ranked as the $11^{\text {th }}$ producer of oil globally (Varrella, 2021) and her contribution to the global market is significant. In 2016, the Federal Government adopted a strategy aimed at revamping the sector by boosting local production capacity and overcoming the incessant challenge of fuel scarcity in Nigeria through modular refineries (Obioma, 2021). Bills to develop private modular oil refinery projects were initiated and passed by the National Assembly. Among those licensed to refine petroleum products are the Petroleum firm, Dangote refinery, Lekki Free Zone and others. The objective is to also encourage local content in the refining of crude oil which is far from being achieved, according to KPMG (2019).

In January, 2021, the President informed Nigerians that 5,000 barrels per day Waltersmith Modular Refinery is completed in Imo State and another large capacity modular refinery is located at Edo State (Obioma, 2021). Nigerians are yet to benefit from the dividends of the modular refineries as pump prices of petroleum products are very unpredictable and ever increasing while some parts of the country have to deal with the incidence of scarcity of the petroleum products. 
The Federal Government under the leadership of late President Musa Umaru Yar'adua recognized the dire need to carry out total restructuring of the oil and gas industry's legislative framework (African Business, $29^{\text {th }}$ September, 2021) and therefore mandated the reconstituted OGIC to come up with a draft oil and gas reform bill. The PIB is an offshoot of the OGIC report which was presented to the National Assembly for the first time in 2008. In July 2012, the PIB which was modified went back to the Nigerian National Assembly.

The PIB was not passed after several attempts on the basis of the disagreement between the National Assembly and the Presidency, the disregard of ministerial powers and control, concerted resistance by the host communities to petroleum products and uncooperative attitude of investors who felt that the provisions made were not favourable to their businesses according to Ikwueto and Akpan (2021). Jubril and Abdullahi (2020) reported that IOCs stopped the investment of \$40billion dollars while awaiting the passage of the bill.

Eventually, the bill was passed into an Act in July, 2020, after 13 years. The aim of the Petroleum Industry Act (PIA) is to achieve a total transformation of the oil and gas industry by addressing issues bordering on the provision of consolidated laws/legislations to manage waste, improve community-industry relations and deal with corrupt practices (Enedi, 2021). The Act is to make the industry more attractive to investors whose activities will boost the economy. Ikwueto and Akpan (2021) are of the opinion that the PIA serves as a catalyst in the industry and provides a comprehensive and uniform benchmark for the regulation of the industry. However, they raised some concerns such as the lopsided provisions for the host communities and the role of the NNPC in terms of ownership of the company and the managerial control of the system. These issues unfortunately are germane to the comprehensive definition of the PIA.

The Federal Government recently introduced the 'Decade of Gas' project with the aim of achieving an economy powered by gas in the 2030. This project is to collaborate with Nigeria's National Gas Expansion programme which was launched to boost gas production to be consumed locally by households, organizations and industries. Nigeria gas resource is ranked among the largest 10 globally (African Energy Chamber, 2021). Ironically, the cost of cooking gas is on the increase. For example, $12 \mathrm{~kg}$ cylinder of gas has moved to N8, 758.00 as at October, 2021 (TheGuardian, $30^{\text {th }}$ October, 2021).

\section{Challenges in the oil and gas sector in nigeria}

One of the problems is that the Ministry of Petroleum Resources is structurally a body set up and governed by the Nigerian Civil Service and according to Egbogah (2013), keen industry observers are of the pinion that it does not have the capacity and capability to make complex policies required to regulate the equally complex oil and gas industry. The Department of Petroleum Resources (DPR) which is responsible to the Ministry of Petroleum Resources also has some constraints in the discharge of its duties. Egbogah (2013) and Iruoma (2021) opined that NNPC, also a state-owned company is being bedeviled by all the usual bureaucratic tendencies, lack of commitment and corruption.

PwC reported in 2016 that some multibillion dollar transactions executed by NNPC had discrepancy problems of more than \$20billion in the total value of crude oil sales and consequently recommended that NNPC should be overhauled. The issue of the missing money was not resolved (Akinola, 2015). This brings to question the integrity of the state-owned company. Barclay (2016) has this to say about NNPC: 'NNPC's operations are replete with patronage, favouritism and political interference, supporting a political system that thrives off its opacity and dysfunction'. In essence, the activities of NNPC are undermined by poor management of records, lack of transparency and accountability and large scale secrecy in all the processes involved in the award of contracts and licenses (Olujobi, 2021).

Nigeria has the capacity to build up its level of oil production on a daily basis. However, Hamil (2015) in explaining the causes of the under-capacity experienced in the oil and gas sector stated that heavy Government involvement, legislative uncertainty, corrupt practices, and high level of oil theft are some of the problems. As a result of large-scale pipeline vandalism, alarming state of insecurity in the Niger Delta region, challenges in the Federal Government's implementation of the Joint Venture Agreements, many of the IOCs divested and sold off their shares. Moreover, they considered the onshore/shallow water projects as unviable in terms of profit maximization for the sustenance of their businesses (Hamil, 2015; Kullasingam, Beggs, Tennant \& Douglas, 2015).

The Nigerian Government had a problem with keeping its own part of the Joint Venture Agreements with the IOCs who have complained about it regularly. According to the IOCs, for some years, the budgetary allocations are often short of the requirements and this has had adverse impact on the capital expenditure requirement for increasing production (Egbogah, 2009). Chika (2016) stated that NNPC was indebted to their partners to the tune of $\$ 2.839$ billion which translates to N567.76 billion. NNPC blamed it on the low revenues from crude oil sales but this happens irrespective of the fact that the last time the organization remitted proceeds from crude oil exports to the national account was in March, 2015. NNPC's failure to meet its funding obligations consequently brought about a reduction in exploration and production activities. 
Egbogah (2009) and Olujobi (2021) also added that there is the challenge of inadequate infrastructure and commercial framework which are required for adequate supply that would meet the market demand. The problems of persistent inability of the government to develop key laws and non-implementation of reforms have contributed immensely to the ever-present lacuna in the policy making process and implementation of reforms. The above factors and strategic uncertainty plaguing the oil and gas sector account for the low rate of investment in the sector according to Barclay (2016).

Moreover, the issue of the neo-imperialistic tendencies of the IOCs still undeniably remains a clog in the wheel of the development of the oil and gas sector as they do everything possible to remain in control of the Nigerian economy. IOCs were accused of complicity in the destructive conflicts witnessed in the Niger Delta region in the height of the unrest. They had also been accused of taking part in crude oil theft which has plundered the Nigerian economy (Boris, 2015).

Compliance with reforms and policies in the sector is not taken seriously by IOCs as they continue to operate to satisfy their selfish capitalistic interests. The National Gas Policy in 2017 provided policies for all the segments of the oil and gas industry and proposes to commercialize gas which will serve as a panacea to the gas flaring challenge in Nigeria. In addition, the PIA is also against gas flaring (KPMG, 2021). However, the inability of the Nigerian State to achieve success in implementing the policy against gas flaring is hinged on poor regulatory framework (Elebiju \& Odupe, 2021). The numerous deadlines dating as far back as 1974, approved to stop gas flaring have not yielded complete results so far. The Vice-President, Prof. Yemi Osinbajo, disclosed in 2016 that Nigeria is set to target 2020 to end gas flaring (The Will, March 14, 2016). The deadline has come and gone, but gas flaring still persists in Nigeria (Elebiju \& Odupe, 2021).

There is a relationship between oil theft and money laundering which involves international syndicates (Asuni, 2009; Katsouris \& Sayne, 2013) cited in Boris (2015). It is taken that the Niger Delta youths may be involved in the siphoning and loading of the crude oil but the financing, transportation, and the illegal transfer of the money involved are carried out by international players from Eastern Europe, Russia, Australia, Lebanon, the Netherlands, and France (Coventry Cathedral, 2009) cited in (Boris, 2015).

Gboboye, Soreide, Le and Shukla (2011) drew a link between the challenges persisting in the regulation of the oil and gas sector in Nigeria and ineffective governance. It was posited that the following factors are responsible for the poor performance: monopolistic executive control on petroleum activities characterized by weak checks and balances; a situation where one institution performs the dual function of carrying out operations and regulating the industry at the same time thereby creating a conflict of interest; and undue influence on electoral outcomes and political patronage.

\section{SO FAR, HOW FAR?}

Laba (2012) stated that the Local Content Act achieved some of its objectives as some companies started using locally made products and services. Exxon is one of such companies that implemented the policy to an extent; many young Nigerians were trained and also employed in the sector. However, Temitope (2015) differed with Laba's opinion and argued that a critical analysis of the oil and gas sector shows that the Local Content Act has not achieved its full objectives. In other words, it has made very little impact on the economy and people. She added that the level of local involvement is low considering the viability, potentialities, and capacity of the sector; factors which can significantly raise living standards and create employment for Nigeria's teeming population.

On the question of if Nigerians have the professional knowledge/experience and skills required for the job, Temitope (2015) affirmed that Nigerians possess the required expertise and skills for an effective and efficient performance in the sector. She is also of the opinion that the Local Content Act was handicapped by what would be described as deliberate man-made barriers by both local and international players and that by way of comparison, countries like Venezuela and Saudi Arabia have a higher level of local content implementation (Temitope, 2015).

President Olusegun Obasanjo met the oil and gas sector in a bad state when he assumed office in 1999 and Daily Independent (May 2, 2006) reported that he made remarkable efforts at transforming the sector by ensuring that the investment decision making process was transparent; he promoted accountability in the oil and gas earnings, bringing about international audit in the sector from 1999 to 2004, and transparency in the award of the controversial oil blocks. However, Aghalino (2005) had argued that oil blocks were allocated at the whims and caprices of the President without passing through due process which he preached during his tenure.

For over 12 years, only 9 out of the 30 marginal fields which were awarded to local companies were developed by 2015. It was however reported that there was a threat to revoke about 18 non-performing marginal fields and the deadline was March, 2015. Surprisingly, the licenses were not revoked and nobody knew the reason (Kullasingam et al., 2015). 
NNPC plays a strategic regulatory role in the oil and gas sector but it was indicted in a report by the Hartgroup, a U.K based independent auditor which was mandated by the Nigerian Extractive Industry Transparency Initiative (NEITI) to audit NNPC's financial records (Diakolo, 2006) cited in Aghalino (2006). The report showed that NNPC could not account for the sum of \$250million and \$1,265million which were proceeds from the sale of crude oil between 1999 and 2005. This is in addition to about 10 million barrels of crude oil which were not also accounted for in 2006 (Sunday Vanguard, June 25, 2006).

Despite the level of reformation that had taken place in the oil and gas sector and the accompanying legislations over the issue of tax on profit, massive tax invasion and unethical practices are perpetrated by the oil companies. Chevron was accused of withholding petroleum profit tax of US\$994 million for a period covering December, 2003 and November, 2004 by padding overhead costs (Daily Independent, Tuesday, May 2, 2006) but was not prosecuted according to the provisions of the laws.

With the already nose-dived price of crude oil in the international market, the problem of under-production of crude oil and high foreign exchange rate escalated. Because of the COVID-19 pandemic which broke out in 2019, the country has been thrown into a number of conditions including an economic recession (Afaha, Aderinto, Oluwole, Oyinlola \& Akintola, 2021) in addition to intensified armed insurgency from different parts of the country.

Globally, Nigeria is recognized as a major producer of crude oil but shockingly, the country's reliance on the importation of refined petroleum products has reached an alarming rate according to Olujobi (2021). Unfortunately, the importation of petroleum products has not guaranteed a regular supply of fuel and other petroleum products amid the ever increasing pump prices. It has however been observed that the proliferation of illicit refineries also known as 'oil bunkering' may have alleviated the sufferings of thousands of Nigerians because of the relative availability of fuel.

In recent times, the 'oil bunkering' business which has somewhat become a source of economic empowerment for the teeming unemployed youths, especially from the Niger Delta regions has posed both environmental and health challenges. The activities in these illicit local crude oil refineries account for the present day black soot air pollution which the residents of Rivers State are forced to inhale on a daily basis (Elem, 2021). The activities of such people are going on unabated.

\section{CONCLUSION}

The paper adopted the concept of Pockets of Effectiveness to explain that even in the midst of such decay, Government agencies and public organizations stand a chance of achieving effectiveness by eschewing the mentality of rent-seeking, patronage, clientelism and corruption through good governance. So far, the PIA is said to have the potency to create value in the oil and gas sector and will deal with issues bordering on corruption and transparency. However, a lot depends on Nigeria's willingness to always think outside the box and eschew all forms of selfish alignments including political, religious and ethnicism.

\section{REFERENCES}

- Afaha, E., Aderinto, A., Oluwale, E. A., Oyinlola, A., \& Akintola, Y. (2021). Effect of covid-19 on the Nigeria oil and gas industry and impact on the economy. CPEEL's covid-19, (11)

- African Energy Chamber. (2021). www.AEW2021.com.

- Aghalino, S. (2005). Gas Flaring, Environmental Deterioration and Abatement Measures in Nigeria; 1958-2001'. Journal of Third World Studies, (1), 21-23.

- Aghalino, S. (2006). Niger Delta region and the struggle for resource control: implications for the nascent democracy. in: Eo Ojo (ed): challenges of sustainable democracy in Nigeria: John Archers Publications

- Ahimie, U. (2020). Understanding the deregulation of the downstream oil and gas sector in Nigeria. Nairametrics.

- Ameh, M. (2006). The shift from joint operating agreement to production sharing contracts in the Nigerian oil and gas industry: any benefit for the players. The Centre for Energy, Petroleum and Mineral Law and Policy Annual Review.

- Anderson, A. (2005). The Community Builder's Approach to Theory of Change: A Practical Guide to Theory Development: Aspen Institute Roundtable on Community Change.

- Barclay, R. (2016). Strategic Outlook for Nigeria's Energy Sector. Tim Newbold. inewbold@ africapractice.com.

- Boris, O. (2015). The Upsurge of Oil Theft \& Illegal Bunkering in the Niger Delta Region, Nigeria: Is there a Way Out? Centre for Population \& Environmental Development, 3(6).

- Chika, I. (2016). Nigeria's oil and Gas Sector Hangs in the Balance in 2016. Leadership Journal, 1(1).

- Diakolo, D. (20 April, 2016). Obasanjo and the petroleum industry, 1999-2005. The Daily Independent, (Lagos), Thursday, April 20.

- Donwa, P., Mgbame, C., \& Ogbeide, O. (2015). Corruption in the Nigerian oil and gas industry and implications for economic growth. International Journal of African and Asian Studies, 14, 2409-6938. 
- Ebeide, T. (2017). Instability in Niger Delta: post amnesty programme and sustaining peace-building. Friedrich-EbertStitung peace and security center of competence Sub-saharan Africa. Mammalian Publication.

- Egbogah, E. (2009). Key Features of Oil and Gas Industry Reforms. A Paper presented at the $2^{\text {nd }}$ India-Africa hydrocarbon Conference.

- Egbogah, E. (2013). Oil and gas sector reforms in Nigeria: what you should know. http://dregbogah.com/documenteds/69.html.

- Elebiju, A., \& Odupe, D. (2021). Nigeria: cessations and destinations: issues in gas flare commercialization in Nigeria. MONDAQ.

- Elem, M. (2021). Black soot and public health of Rumuolumeni Residents in Port Harcourt, Nigeria. Direct Research Journal of Social Sciences and Educational Studies, 1(18), 9-13.

- Gboyega, A., Soreide, T., Le, M., \& Shukla, G. (2011). Political economy of the petroleum sector in Nigeria. Policy research working paper. The world bank, Africa region, public sector reform and capacity building unit. Pearl Publication.

- Hamil, R. (2015). Nigeria: oil and gas: challenges facing the new government. Kent Publisher

- Ibah, L. (10 Oct. 2000). Long Road to Misery: 40 years of Oil and Gas. The Punch.

- Ikwueto, I., \& Akpan, U. (2021). Review of the petroleum industry bill (PIB) 2021. Kenna Partners Publisher.

- Iledare, O. (2008). Petroleum and the future of Nigeria: challenges, constraints and strategies for growth and development: IPS Monogragh Series.

- Joab-Peterside, S. (2015). Reforms in the oil and gas sector in Nigeria from 1999 - 2012: prospects and challenges. A Publication of the Port Harcourt Journal of Social Sciences, University of Port Harcourt, 1(6), 1 - 2.

- Jubril, Y., \& Abdullahi, M. (2020). Challenges and reforms in the Nigerian oil and gas sector. SSRN Copy Publisher.

- Kelly, M. (2015). Nigeria's oil industry reforms. Martin.kelly@woodmac.com

- $\quad$ KPMG in Nigeria, 2019.

- $\quad$ KPMG in Nigeria, July 2020.

- KPMG in Nigeria. (2021). Petroleum industry bill. A game changer? kpmg.com/ng.

- Kulasingam, R., Beggs, D., Tennant, D. H., \& Pipe, T. (2015). Outlook for the Nigerian oil and gas market. Mondag Publication.

- Laba, O. (2012). Appraisal of Reform in the Oil and Gas Sector. https//www.thenigerianvoice.com.

- $\quad$ Maduekwe, C. (2016). President Buhari's Change Agenda in the Petroleum Sector. Premium Times.

- $\quad$ NNPC newsletter (2021). History of the Nigerian petroleum industry.

- Nwapi, C. (2019). The achievement of regulatory excellence in the oil and gas industry in Nigeria. The 2017 National Oil and Gas Policy. Journal of Energy and Resources, (38).

- Obioma, C. (17 ${ }^{\text {th }}$ Aug. ,2021). Refineries and fuel sufficiency. Vanguard newspaper.

- Ogbuigwe, A. (2018). Refining in Nigeria: history, challenges and prospects. Applied Petroleum Research (8), 181-192.

- Ogen, O. (2003). Patterns of economic growth and development in Nigeria since 1960. In. Arifalo S. And Gboyega Ajayi (eds.). Essays in Nigerian contemporary history: First Academic Publishers.

- Oladunjoye, M. O. (2013). Incorporated Joint Ventures in the Nigerian Petroleum Industry: Examining the Legal Implications and Regularity Risk. OGEL, (11), 1875-418.

- Olaniwun, A. (2013). Nigeria, freshfields bruckhans deringer. Freshfields.com.

- Olujobi, O. (2021). Deregulation of the downstream petroleum industry: an overview of the legal quandaries and proposal for improvement in Nigeria. Heliyon, 4(7), 4. https://doi.10.1016?..heliyon.2021.06848.

- Olujobi, O. S. (2021). Nigeria's upstream petroleum industry anti-corruption legal framework: the necessity for overhauling and enrichment. Journal of money laundering control, 3(2), 1368-5201.

- PcW. (2021). The petroleum industry act. Redefining the Nigeria oil and gas landscape. www.pwc.com/ng.

- PwC: www.pwc.com/ng

- Resolution Law Firm. (2020).

- Roll, M. (2014). The politics of public sector performance: Pockets of effectiveness in developing countries. Doi.10.4324/9781357718.

- Saidu, S., \& Abdel, R. (2014). The Nigerian Petroleum Industry Bill: An Evaluation of the proposed Fiscal Terms on Investment in the Upstream Sector'. Journal of Business and Management Sciences, 22, 45-57.

- Temitope, O. (2015). The local content act 2010 and the Nigerian oil and gas sector. a Paper presented at the CSO/Media Meeting organized.

- Varrella, S. (2021). Oil industry in Nigeria- statistics and facts. Statista. www.statista.com.

- Vogel, I. (2012). The United Kingdom Department of international development the review of the use of 'theory of change' in international development. Review Report. www.Isabelvogel.co.uk

- Wapner, N. (2017). Downstream beneficiation case study: CCSI Policy Paper.

CITATION: Mmecha Helen Oziri \& Mmecha Christopher Achinike (2022). Reforms in the Oil and Gas Sector in Nigeria from 1999 - 2021: A Critical Appraisal. South Asian Res J Human Soc Sci, 4(1): 26-33. 